this; to say that volunteers are ignorant and inexperienced is to belittle the whole profession and degrade it in the eyes of the people. They both are lacking in some qualifications to make the best type of medical officers; many of the volunteers are lacking in military medicive, particularly as regards red tape, etc., and the regular in experience in general medicine and surgery. The combination of the regular and volunteer would make the ideal medical officer. If the regular profits by his experience in this war, and the volunteer by his, aud they work together harmoniously in the future, the question of good army medical service will be solved. Let us not give way to personal feelings, criticising physicians who have done the best they could under the circumstances, and who bave perhsps dowe better than we could under the same conditions. Let us note our imperfections and try to improve the service for those who succeed us. Contributions furnished by experience will be a great aid to our successors. Exaggerated and sensational accounts of mismanagement do no good.

Some of the important improvements in our State service the past five years are as follow :

(1) Physical examination of recruits; at first voluntary and now made mandatory.

(2) Rition to be used at camp. Something after the pattern of army ration, but modified for adaptation to State service. ally.

(3) School for medical officere. One session snnu-

(4) Company bearers; four privates in each company specially trained in emergency and first-aid work.

(5) System of red tape patterned after regular army, but modified for State service.

I have merely touched upon certain suggestions which could well bear elaboration, but tiwe and spaco forbid.

'The following is a brief résumé of the suggestions offered to improve the efficiency of the army medical service. Some of them have been practically adopted by the Massachusetts Volunteer Militia, and it is hoped will be adopted by the entire Nutional Guard:

(1) That professorships of military medicine be established in every reputable medical college.

(2) That until such time as professorships are established, the State provide a course on required sub. jects.

(3) That physical examination of officers and men be made mandatory.

(4) That troops at State encampments conform as nearly as possible to duties required in service on the field.

(5) That every medical officer receive commission. (This pertains to contract surgeons.)

(6) 'That one or more men in every company be detailed for regular instructions in ambulance corps, to prevent possibility in the future of the country losing the service of men especially trained for this service.

(7) That one medical officer be selected in each regiment or brigade for his surgical ability.

(8) That a corps of trained female nurses be orgavized in every State.

(9) That divisional hospitals, in the broad sense, be abolished, and that small brigade and divisional hospitals be established for opecial cases, such as surgical and contagious.

(10) That the volunteers follow, as closely as prac- ticable, the regular army, so that when called into service together the two branches may work in harmony.

(11) In addition to the present instruction in "first aid," a course in prevention of contagious diseases, etc., be given.

(12) That a reserve staff of medical officers be formed in each State : said staff to be composed of exmembers of the medical department of the National Guard.

\section{Olinital EDepartment.}

\author{
UNUSUAL DIASTOLIC MURMUR, WITH \\ AUTUPSY. \\ BY RICHARD E. RDES, M.D., \\ District Physician, Boston Dispensary, \\ AND \\ RICHARD M. PEARCE, MT.D. \\ Instructor in Pathology, Harvard Medical School.
}

THE following case seems worthy of record as helping to throw light on the causation and character of aortic murmurs, as well as for the other uncommon pathological conditions present.

The patient was a business man of active life, married, fitty years old, short and rather stout. No alcoholic or venereal history. Sciatica about five years, aud a ruptured varicose vein about three years previously, during which sickness his physician said nothing to him or his family about the existence of beart trouble. About a year previously he lust most of his sleep for a few nights on account of pains resembling muscular rheunation in his right shoulder, arm and forearm, but these practically all disappeared and did not return.

On February 18, 1899, he realized that something serious was the matter with him, having had a very restless and uncowfortalle night, and complaining also of a "scraping" in his chest. 'This he said he had felt for about six months, but had thought to be only bronchitis! Some weeks previously he had had au attack of dyspuea after climbing stairs, but had soon recovered; and again, during the heavy snowstorm on February 13th, he had nearly collapsed between the train and his house, one-quarter mile, and had been feeling rather poorly since, although going actively about. His breathing on the nights of February $17 \mathrm{th}$ and 18th, as described by his wife, was Cheyne-Stokes.

A hasty examination gave a loud "scraping" murmur and thrill at the base of the heart, seening systolic at first, as it was accompanied by a heave in the apex region, ulthough by no definite apex beat which could be felt.

Further study developed the following picture: The apex beat could be felt very feebly at times in the sixth interspace, one inch outside the nipple in the dorsul position, and in the left side position quite distiuctly a trifle further out. The heave was diastolic, very marked, and at times a distinct diastolic impulse, alternating with the true apex beat and with the carotid pulse, could be felt in the fourth and fifth interspaces iuside the nipple. The heart dulness was enlarged, corresponding to the position of the apex, and the lower sternum was duller than normal. Later the lower steruum became quite flat to percussion and dulness extended about one-half inch to the right. 
The liver was slightly enlarged. Two murmurs, a systolic and a diastolic, were heard all over the heart area; the systolic blowing, slight at the apex (where a slight but sharp first sound was heard), very distinct at the base, louder in the first right interspace, and loudest just above the inner end of the clavicle, where it became louder than the diastolic nurmur and was accompanied by a systolic thrill and an impulse much more marked than above the left clavicle. There was no especially strong pulsation in the suprasternal notch. The diastolic murmur was heard all over the chest, loudest at the second right interspace, and could be heard without the stethoscope three or four feet away from the patient. It was accompanied by a powerful diastolic thrill felt all over the upper front chest. The character was best described as "scraping." although at times it was almost musical. It never intermitted or very markedly changed in character or intensity. The pulse, averagiug about 92 , was a fairly marked water-hammer, fairly strong, with an occasional occurrence of pulsus intercidens. A sphygmographic tracing showed the same characters, with 80 sharp a rise as to make auy marked degree of stenosis very improbable. 'There was no marked arteriosclerosis of the brachials, radials or temporals.

The course of the disease was steadily but slowly downward, with a much congested liver, edema of legs, distressing attacks of orthopnea at times, congestion of veins of neck, and gradually rising a verage rate of pulse. Abqut one month before death, which was on May $218 t$, the right radial pulse became distinctly Weaker than the left and remained so, and about this time a dulness not detected before was made out, involving the upper sternum and a bit of the first interspace to the right. A alight hoarseness on March 11 th, lasting about a week, seemed to be of inflammutory origin, as the temperature was slightly elevated on the first day. The Cheyne-Ștokes breathing became more frequent but not constant, and the death was one of exhaustion and gradual failure. 'There was practically no pain at any time.

The autopsy showed the following conditions: There was marked passive congestion of liver, spleen and kidneys; moderate hydroperitoneum, hydrothorax and hydropericardium; arterio-sclerosis was not general. 'The heart was moderately hypertrophied (415 grammes), with quite an amount of epicardial fat, the left ventricle and left auricle considerably dilated, and the heart muscle showed marked fatty degeneration. The corouary arteries showed no chavges, except just at the beginning of the left, where there were one or two yellowish non-calcareous patches; these did not seem of sufficient importance to cause the fuilure to compeusate. The aortic valves were distinctly but not extremely incompetent, the circumference being nearly normal (8.4 centimetres) and the leakage being due to a shortening of the anterior cusp. Just above the junction of the anterior and left posterior cusps was an aueurismal pouch 1.2 by 2 centimetres in diameter and 1.6 centimetres deep, the edges slightly overhanging, containing no thrombi. The orifice of this cavity was in contact with the anterior cusp of the valve, which was somewhat shortened thereby, giviug rise to the incompetence just mentioned. At the junction of the anterior and left posterior cusps there was a small area of subendocardial hemorrhage. The bottom of the aneurism was opposite the left auricle, the endocardium of which was thickened at this point over an area thres centimetres in diameter. The aorta showed a dilatation of the arch and descending portions. This dilatation was most marked in the ascending and transverse portions of the arch and gradually diminished to a point opposite the second iutercostal arteries. At a point four centimetres above the aortic valves the circumference of the aorta was 13.5 centimetres. Calcareous plates were very numerous and over some of them the intima had entirely disappeared, leaving small, roughened, blood-stained areas. There were also seen a few flattened areas, non-calcareous, but containing a soft yellowish material.

The orifice of the innominate artery measured two centimetres in diameter ; one centimetre above this orifice was a sacculated dilatation 3.5 centimetres in diameter, to one side of which adhered a firm grayishred thrombus. This aneurism extended up to the division into carotid and subclavian, which vessels were compressed by the thrombotic mass. 'The vessels, however, were pervious.

In the right auricle, occupying the auricular appendage and extending into the auricle proper, was an adherent mass five by three centimetres, grayish red on surface, on section showing a softened centre of yellowish, granular material. Right side of heart otherwise negative.

In regard to the interpretation of the clinical signs by the pathological findings, the weak right radial pulse was of course due to the innominate aneurism. The systolic murmur and thrill were probably also produced in this aneurism or possibly in the opening between it and the aorta. It will be noted that no aortic stenosis was present.

In regard to the duluess of the upper sternum and first right interspace detected about a month before death, it would seem as if some change must have taken place during the course of the disease, consisting either of an enlargement of the innominate aneurism, of increased congestion of the innominate veins, of more careful percussion, or perh

Now as to the most marked feature of the case, the unusually loud and rough diastolic murmur, was it caused by the aortic aneurism alone, by the incompetent valve alone. or by the combined eff rets of the two? To the first hypothesis is opposed the great difficulty of explaining why the effect of the systole and diastole should be so different. As to the second, loud diastolic murmurs are mentioned by a number of authors (Bramwell, Gibson, Broadbent, Steele, and others), and a number of cases are on record. In those cases, however, which do not have a special cause for the loud murmur, such as a torn valve flap, e:c., the murmur is generally musical, or intermittent, or both. All, or nearly all such cases, show extensive arterio-sclerosis, as did this case in the aorta and some of the large ressels. It would esem then reasonable to expect to find in each case of rough diastolic nurmur a special cause over and above a leaky valve. In this case the mode of production of the murmur may be imagined in this way, that the regurgitant blood current, instead of flowing smoothly through the valves, causing fiue vibrations and a soft murmur, formed a whirlpool in the small aneurism, becoming turbulent just at its passage through the valves, and thus giving rise to coarse vibrations and a loud, rough murmur. It is probable that the dilated and sclerotic condition of the aorta had some influence on the character of the murmur. In this connection it is interesting to note that in 22 
cases of aneurism of the sinuses of Valsalva, ${ }^{1}$ a loca tion slightly nearer the semilunar valve flaps than in our case, no instance of rough, diastolic murmur occurred.

\section{ghedical 翟rogregz.}

\section{REPORT ON MENTAL DISEASES.}

13Y HKNRY R. S'TKDMAN, M.D.

THE FINER CELl CHANGeS in MENTAL PATHOLOgY.

Angiolidia ${ }^{2}$ has made a careful review of the finer changes in the nerve cell in various forms of mental disease. He maintains that the basis of a normal and pathologico-auatomical psychology is but just beginning to appear on the distaut horizon aud that the secret of life and its various functions must be sought in the study of the single cell elements, and their chemical constitution. The change which this constitution undergoes in the various functional states and pathological operations is to be applied to the physiology of the nervous system and is beginning to give results. 'The method of Golgi has permitted us to realize immense progress in our knowledge of the normal morphology of the nerve cell aud to recoguize some slighter pathological changes, such as the atrophy and hypertrophy of the protoplasmic processes and alteration in the shape of the cell body; but Nissl's method has permitted us to recoguize the intimate changes in the cell. Amovg these, the most important are the various changes of chromatolysis, that is, the dissolution and gradual disappearance of the chromutic substance of the cell, which is one of the most frequent and best recognized alterations in various pathological conditions. In all degenerative processes this substance is the first to feel the injury of disturbed nutrition and to be altered by it. Since it is knowu that organic molecules of the highest and most complex chemical constitution and the highest biological signification are the most susceptible to injurious influences and the first to feel their effects, it is fair to suppose that this chromatic substance, Nissl's bodies, is of the highest importance in the constitution of the cell body as producing, accumulating or directing nervous energy. Along with the dissolution of the chromatic substance go alterations in the fibrillary reticulum, with alterations in the shape of the cell body, dislocation of the nucleus and complete destruction of the cell.

Researches upon cases of mental disease are as yet few, aud the changes thus far have been found only in geveral paralysis, some cases of termiual dementia, opilepsy, pellagra and acute delirium. Cases of mania, melaucholia and even of paranoia are apt to die either in a stage of terminal dementia or of some intercurrent disease. Experimental research, however, has given us important aid in the study, especially by investigations on poisoning of auimals by alcohol and lead, auto-intoxication, infection, exhaustion, and the like. In all these conditions we find degenerative changes of the nervous elements, and the logical deduction is that similar changes may occur in man under the same morbid influences aud that these changes may have

1 Reported by Cattell and Steole: Pathological Soclety, Phlladelphia, vol xvili, 1898, p. 203, et seq.

1 Aunall di Novrologia vol xvi., page 362. relation to the functional disturbauces which are seen in these conditions. The excitement or the hallucinations of the alcoholic patient, perhaps the paranoia and the pseudo-general paralysis of chronic alcoholism, the delirium of typhoid and pueumonia, the nervous and mental disturbances of urewia and diseases from autointoxication, and the psychoses from exhaustion, deprivation of nutritive material or excessive nervous worry and defective repair may to-day be put in direct dependence upon the nutritive and morphological alterations of the nerve cell, and especially the cerebral nerve cell. We are also led to believe that ordinary mania, melancholia, sensory delirium, and the epileptic attack way be occasioned, in predisposed subjects, by the action of toxic products upon the system and the nervous elements; so that alcoholic excitement, for example, may have the same pathogenic mechanism as the ordinary maniacal attack and may differ from it only in the nature of the poisonous substance.

'The conception of a psychosis without a corresponding naterial change may fairly be bauished frow our knowledge. We do not yet know why, under the action of the same or different poisons, the forms of mental disturbance are so varied, while the cell alterations are nearly uniform. We are still iguorant if the various methods of alteration aud degeneration have a special siguificance in producing the varied forms of functional disturbance or if the production of morbid phenomena varies in relation to the prevalence of one or another form of degenerative process with the different localization of the lesion or with the individual temperament. We are still iguorant if the diversity of temperament varies with the different composition of the cell element or the varying behavior of the elemeuts to the same stimuli.

\section{ACUTE PSYCHOSIS IN COPROSTASIS.}

Sölder ${ }^{2}$ reports six cases presenting the symptoms of acute delirium associated with intestiual disease. A previously healthy iudividual is suddenly or rapidly attacked with symptoms of violent mental disturbance, without reasonable cause, and after some indifferent prodrowes, lasting a few days. The mental trouble begau with confusion, a loquaciousness, a rapid flow of ideas, an expansive aud excited emotional condition, soon followed by a clouding of consciousness and agitation, which rapidly sunk to symptoms of motor irritation of the simplest sort, grimacing and various automatic movements. The speech became incoherent and there was a tendency to verbigeration; there was sleeplessness and failure of nutrition; the temperature was not elevated. The physical examiuation was negative. Constipation existed in all the cases; death followed in ten to fourteen days. The autopsy showed hyperemia and edema of the brain, marked congestion of the lungs, parenchymatous degeneration of the kidneys, heart and liver, and marked coprostasis in the large intestine, with alterations in the intestinal mucous membrane. 'The history showed that the constipation preceded the mental disturbance, which was regarded as a result of it; and the author concludes that an acute psychosis may be the result of coprostasis aud may run a course similar or identical to that of acute delirium, causing death by weakness of the heart in one to two weeks. One case recovered after complete emptying of the intestine. The author roviews the theories as to the relation between the intes-

S Juhrblicher f. Psych, vol, xvil, p. 174. 